\title{
Virus-like particles associated with heart and skeletal muscle inflammation (HSMI)
}

\author{
K. Watanabe ${ }^{1}$, M. Karlsen ${ }^{1}$, M. Devold ${ }^{1}$, E. Isdal ${ }^{2}$, A. Litlabo ${ }^{3}$, A. Nylund ${ }^{1, *}$ \\ ${ }^{1}$ Department of Biology, University of Bergen, Thormøhlensgt 55, 5020 Bergen, Norway \\ ${ }^{2}$ Intervet Norbio, Thormøhlensgt 55, 5020 Bergen, Norway \\ ${ }^{3}$ Havbruksinstituttet AS, Thormøhlensgt 55, 5008 Bergen, Norway
}

\begin{abstract}
The first cases of heart and skeletal muscle inflammation (HSMI), in Atlantic salmon Salmo salar were registered in 1999 in the Hitra/Frøya area of Norway. The disease has since spread south to Rogaland, i.e. the southernmost county with salmon farming in Norway. The disease outbreaks usually start 5 to 9 mo after release into seawater but may occur as early as 2 wk after sea release. The present study focuses on possible pathogens associated with HSMI. It was not possible to find any parasites or bacteria that could explain HSMI, and none of the well-known viruses (infectious salmon anaemia virus, Norwegian salmonid alphavirus, infectious pancreatic necrosis virus, Atlantic salmonid paramyxovirus) were consistently present. Use of transmission electron microscopy showed the presence of epitheliocystis agent in 3 of 4 farms included in this study, and several virus-like particles. Type I and Type II virus particles, previously described for salmon suffering from haemorrhagic smolt syndrome (HSS), and erythrocytic inclusion body syndrome (EIBS) virus were consistently present in salmon suffering from HSMI in all 4 farms included in this study. The 2 HSS viruses (Type I and Type II) were also cultured in Atlantic salmon kidney (ASK) cells from salmon suffering from HSMI. However, a causal relationship between the observed virus particles and HSMI remains to be demonstrated.
\end{abstract}

KEY WORDS: HSMI · Possible agents · Viruses

Resale or republication not permitted without written consent of the publisher

\section{INTRODUCTION}

Heart and skeletal muscle inflammation (HSMI) was registered for the first time in 1999 in western Norway in the Hitra/Frøya area and the disease has since been present in these areas (Watanabe et al. 2003, Kongtorp et al. $2004 \mathrm{a}, \mathrm{b})$. The disease outbreaks start 5 to $9 \mathrm{mo}$ after release into seawater of Atlantic salmon Salmo salar weighing between 0.4 and $1.0 \mathrm{~kg}$. However, in 2004 the disease was observed as early as 2 wk after release in some marine farms in western Norway. Increased mortality in net pens affected by HSMI last about 2 mo. Fish suffering from HSMI are usually oriented towards any sea current in the pens; they are slow moving, but show no other external signs of disease. The fish show clear signs of circulatory failure and have ascitic fluids in the pericardial and perivis- ceral cavities, a pale and soft heart, and sometimes a white layer of fibrin on the liver. The haematocrit values can be normal but may be as low as 10 . Histological sections show changes in nearly all tissues. Degeneration of heart and somatic muscle fibres followed by infiltration of immune cells is a common finding in the atrium, ventricle and the somatic musculature (Watanabe et al. 2003). The changes in the heart tissues differ, however, from those observed in salmon suffering from cardiac myopathy syndrome (CMS) (Ferguson et al. 1990, Nylund 2001). The mortality in affected net pens is usually less than $10 \%$, but close to $100 \%$ of the fish in the pen may show changes in the heart and somatic muscle tissues.

The disease is believed to be contagious (Watanabe et al. 2003, Kongtorp et al. 2004a,b). It has been observed that mortality may start in one pen and later spread to 
other pens. Some farms suffering from HSMI have received smolt that came from hatcheries with hemorrhagic smolt syndrome (HSS), a disease that has been associated with 2 virus-like particles (VLP) (Nylund et al. 2003). It is, however, not known if HSS may in some way be connected to outbreaks of HSMI in seawater.

The aim of the present study is to look for known disease agents with the help of existing diagnostic tools and possible new disease agents with the help of transmission electron microscopy (TEM). A selection of different tissues (gills, heart, kidney, somatic muscle, liver, pancreas, spleen) from salmon suffering from HSMI, in 4 different marine farms, was screened.

\section{MATERIALS AND METHODS}

Atlantic salmon Salmo salar suffering from HSMI were collected in 4 different farms shortly after the onset of mortality; 2 farms in Trønderlag, 1 in Møre og Romsdal, and 1 in Hordaland. The mortality in all 4 farms, during the outbreak, was close to $10 \%$. The salmon collected, 10 in each farm, showed few external signs of disease, but displayed abnormal swimming behaviour staying near the cage wall facing the sea current. The histopathology in all fish was consistent with that described for HSMI (Watanabe et al. 2003, Kongtorp et al. $2004 a, b)$. One of the farms included in this study experienced HSMI $14 \mathrm{~d}$ after the smolt were released into seawater. The smolt had a history of HSS in the freshwater phase. HSS was diagnosed by the local veterinary service, and our findings when examining the fish were those as described for HSS in earlier studies (Rodger \& Richards 1998b, Nylund et al. 2003). Samples of the smolt $(\mathrm{N}=10)$ suffering from HSS, at the freshwater site, were also taken and included in the study. Fish at the other 3 farms had the 'classical' HSMI symptoms, which started about 8 mo after release. The disease in these farms was first diagnosed by the veterinary service and confirmed by us when the material below was collected (cf. Watanabe et al. 2003). There are no known connections between the 4 farms containing salmon suffering from HSMI. The following tissues were collected from all salmon and fixed in a modified Karnovsky: gills, heart, kidney, liver, spleen, somatic muscle and pancreas. The same tissues were also frozen in liquid nitrogen for later screening by real time RT-PCR and for cell culturing.

Cell culture. Tissue homogenates of kidney and heart from all salmon in 3 of the farms (excluding 1 of the farms from Trøndelag) sampled was inoculated onto 2 different cell cultures; Atlantic salmon kidney (ASK) cells and Chinook salmon embryo (CHSE) CHSE-214 cells. Salmon from each individual farm were pooled before homogenization and inoculation onto cell cultures.
The cells were cultured in $15 \mathrm{~cm}^{2}$ tissue culture flasks (Nunc) at $20^{\circ} \mathrm{C}$ in Eagle's minimum essential medium (EMEM) (Sigma) supplemented with $10 \%$ foetal bovine serum (FBS) $(10 \% \mathrm{v} / \mathrm{v}), \mathrm{L}$-glutamine (4 mM) and gentamicin $\left(50 \mu \mathrm{g} \mathrm{ml}^{-1}\right)$. The cells were then subcultured for 7 to $10 \mathrm{~d}$ until the tissue flasks were covered with a 60 to $80 \%$ confluent monolayer. Homogenates were diluted 1:100 in EMEM, with added fungizone and antiinfectious pancreatic necrosis virus (IPNV) (neutralizing antibody), incubated for $30 \mathrm{~min}$ at $14^{\circ} \mathrm{C}$, sterile filtered $(0.22 \mu \mathrm{m})$, after which $1 \mathrm{ml}$ was added to cell culture flasks with the monolayer cells at $14^{\circ} \mathrm{C}$. After $30 \mathrm{~min}$, supplemented EMEM as described above, but with $2 \%$ FBS, was added. The cells were incubated for $3 \mathrm{wk}$ before passage to a new culture, or if cytopathic effect (CPE) could be observed, the supernatants were inoculated onto a new culture. The control cell cultures received the same treatment as described above, but no homogenates were included in the inoculums.

RNA extraction. RNA was extracted from infected cell cultures and tissues and reverse transcribed into cDNA as described by Devold et al. (2000). The cDNA was used in the different real time PCR assays used for detection of known viruses in Norwegian salmon farming.

Real time PCR diagnostic. Salmon in all 4 farms and smolt from the smolt production site with HSS were tested for presence of infectious salmon anaemia virus (ISAV) (Plarre et al. 2005), Norwegian salmonid alphavirus (NSAV) (Hodneland et al. 2005), infectious pancreatic necrosis virus (IPNV), and Atlantic salmon paramyxovirus (ASPV) by real time RT-PCR using the cDNA obtained as described above (Table 1). Three different tissues, gills, heart and kidney, were screened from all fish. Negative controls for all steps in the processing (i.e. RNA extraction, reverse transcription, and real time PCR) were included for all assays. The reaction mix for the real-time PCR was as follows: $0.5 \mu$ of single-stranded cDNA from the reverse transcription, $6.25 \mu$ TaqMan Universal Master Mix (2×), $900 \mathrm{nM}$ of each primer, and $200 \mathrm{nM}$ of the minor groove binding (MGB) probe. The total volume was adjusted to $12.5 \mu \mathrm{l}$ using RNAase-free water. The reaction cycle was 2 min at $50^{\circ} \mathrm{C}$ (uracil-DNA glycosylase, UNG, activation), $10 \mathrm{~min}$ at $95^{\circ} \mathrm{C}$ and 45 cycles of $95^{\circ} \mathrm{C}$ for $15 \mathrm{~s}$ and $1 \mathrm{~min}$ at $60^{\circ} \mathrm{C}$. The probes contain a fluorescent reporter and a quencher dye whose physical proximity to each other suppresses any light emitted by the reporter. During PCR the $5^{\prime} \rightarrow 3^{\prime}$ nuclease activity of the DNA polymerase releases the reporter dye from the probe, which results in an increase in fluorescence. The reporter dye, 6-FAM, has an emission wavelength maximum of $\lambda_{\max }=518 \mathrm{~nm}$ and is measured by the ABI 7700 sequence detection system (Applied Biosystems). 
Table 1. The primers and probes in the assay mixes produced by Applied Biosystems (ABI). The probes are specific for the region between the primers. IPNV: infectious pancreatic necrosis virus; ASPV: Atlantic salmon paramyxovirus

\begin{tabular}{|lll|}
\hline Primers/probes & Name & Sequence \\
\hline IPNV & & \\
Probe & VP1M2 & 6FAM - tct tgg ccc cgt tca tt - MGBNFQ \\
Forward primer & VP1F & 5'- acc cca ggg tct cca gtc \\
Reverse primer & VP1R & $5^{\prime}$ - gga tgg gag gtc gat ctc gta \\
ASPV & & \\
Probe & PAR6M2 & 6FAM - agc cct ttt gtt ctg c - MGBNFQ \\
Forward primer & PAR6F & 5' - ccc ata tta gca aat gag ctc tat ctt \\
Reverse primer & PAR6R & 5' - cgt taa gga act cat cat tga gct t \\
& & \\
\hline
\end{tabular}

DNA extraction for PCR. DNA was extracted from the gills (1st gill arch) of salmon diagnosed with HSMI in the 4 marine farms, using the DNeasy protocol for animal tissues (Qiagen). The DNA were eluted in $50 \mu \mathrm{l}$ elution buffer (AE) buffer supplied with the Qiagen-kit and stored at $-20^{\circ} \mathrm{C}$ before use in a PCR. This DNA was used in the screening for the epitheliocystis agent Candidatus Piscichlamydia salmonis (Draghi et al. 2004). Positive control tissues (Accession no. DQ310810), collected from salmon in western Norway, were included in all runs.

In addition to the Piscichlamydia salmonis primers constructed by Drahgi et al. (2004) and the touchdown PCR protocol described above, new PCR primers were constructed based on small subunit ribosomal DNA (ssu rDNA) sequences from Candidatus Piscichlamydia salmonis (Accession no. AY462244,). An overview of the new primers is given in Table 2 . The primers designed by Drahgi et al. (2004) were used as described in their publication. The new PCR amplifications were performed in a total volume of $50 \mu$ l using $2 \mu$ l of template DNA and the reaction mixture consisted of; $5 \mu l 10 \times$ PCR buffer, $5 \mu \mathrm{l} 10 \mathrm{mM}$ deoxyribonucleotide triposphate (dNTP), $1 \mathrm{ml}$ (10 mM) of different combinations of reverse and forward primers, $2 \mathrm{U}$ of thermostable DNA polymerase (Qiagen), and $36 \mu$ distilled water $\left(\mathrm{dH}_{2} \mathrm{O}\right)$. The PCR conditions were as follows: after an initial $5 \mathrm{~min}$ denaturation step at $95^{\circ} \mathrm{C}$, samples were taken through 35 amplification cycles, each consisting of a $30 \mathrm{~s}$ denaturation step at $94^{\circ} \mathrm{C}$, a $45 \mathrm{~s}$ primer annealing step at a temperature dependent on the primer combination used, and a $1 \mathrm{~min}$ and $30 \mathrm{~s}$ extension step at $72^{\circ} \mathrm{C}$. A prolonged extension step of $10 \mathrm{~min}$ at $72^{\circ} \mathrm{C}$ completed each reaction.

Histopathology and TEM. All tissues from all the salmon, collected from the farms, were fixed by immersion, at $6^{\circ} \mathrm{C}$, in a modified Karnovsky fixative where the distilled water was replaced by Ringer's solution (Nylund et al. 1995). The fixative contained $4 \%$ sucrose. Before embedding in EPON 812, the tissues were stained/post fixed in $2 \% \mathrm{OsO}_{4}$. Semi and ultrathin sections were cut on Reichert-Jung Ultracut E. The ultrathin sections (30 to $40 \mathrm{~nm}$ ) were stained for $1.5 \mathrm{~h}$ in $2 \%$ aqueous uranyl acetate solution and then stained with lead citrate. Semithin sections, $1.5 \mu \mathrm{m}$, were stained in toluidine blue.

We made semithin sections of all tissues from all the salmon. Based on these semithin sections selections, all tissues from 5 fish in each farm were chosen for TEM studies. There was little variation in the histopathology seen in the fish from the different farms and within farms, i.e. the collected material was very homogenous.

\section{RESULTS}

The macroscopic changes in the salmon suffering from HSMI included a pale heart, ascitic fluids, and a pale or stained liver. The most common lesions in the heart were found in the ventricle where the spongy and compact layers were infiltrated by leukocytes (Fig. 1). These inflammatory cells were localized within and around myofibers. A large number of necrotic myofibers were observed showing condensation, loss of striation, and vacuolization. The somatic muscles, red muscle, were hypercellular and showed loss of striation and vacuolization. The liver showed necrotic foci were cells were vacuolated and pyknotic. Smolt in the freshwater phase suffering from HSS showed the typical signs of this disease (cf. Nylund et al. 2003).

No metazoan or protozoan parasites that could explain HSMI were found during the examination of the fish. Salmon from 3 of the farms had gills that were heavily infected with an epitheliocystis agent (Fig. 2). PCR using primers targeting the $16 \mathrm{~S}$ sequence of Candidatus Piscichlamydia salmonis gave no positive results even though the epitheliocystis agent could be observed on histological section of the gills from all fish. The positive controls were positive in all runs.

Table 2. Primer for detection of candidatus Piscichlamydia salmonis in salmon with epitheliocystis agent on the gills. $\mathrm{Tm}$ : annealing temperature

\begin{tabular}{|llc|}
\hline Primer & Sequence & Tm \\
\hline PIC-F1 & 5'-AAGCACTTTTGCCTGGGAGC & 62 \\
PIC-F2 & 5'-TTTTCGCAATGGGCACAAGC & 60 \\
PIC-F3 & 5'-AATTTAGTGGCGGAAGGG & 54 \\
PIC-R2 & 5'- CCTCAGCGTCAGTATCAATCTAGG & 72 \\
PIC-R3 & 5'- CTTGTTACGACTTCACCC & 54 \\
PIC-R4 & 5'- TCTCCAGTTTGCTCCCAGGC & 64 \\
\hline
\end{tabular}




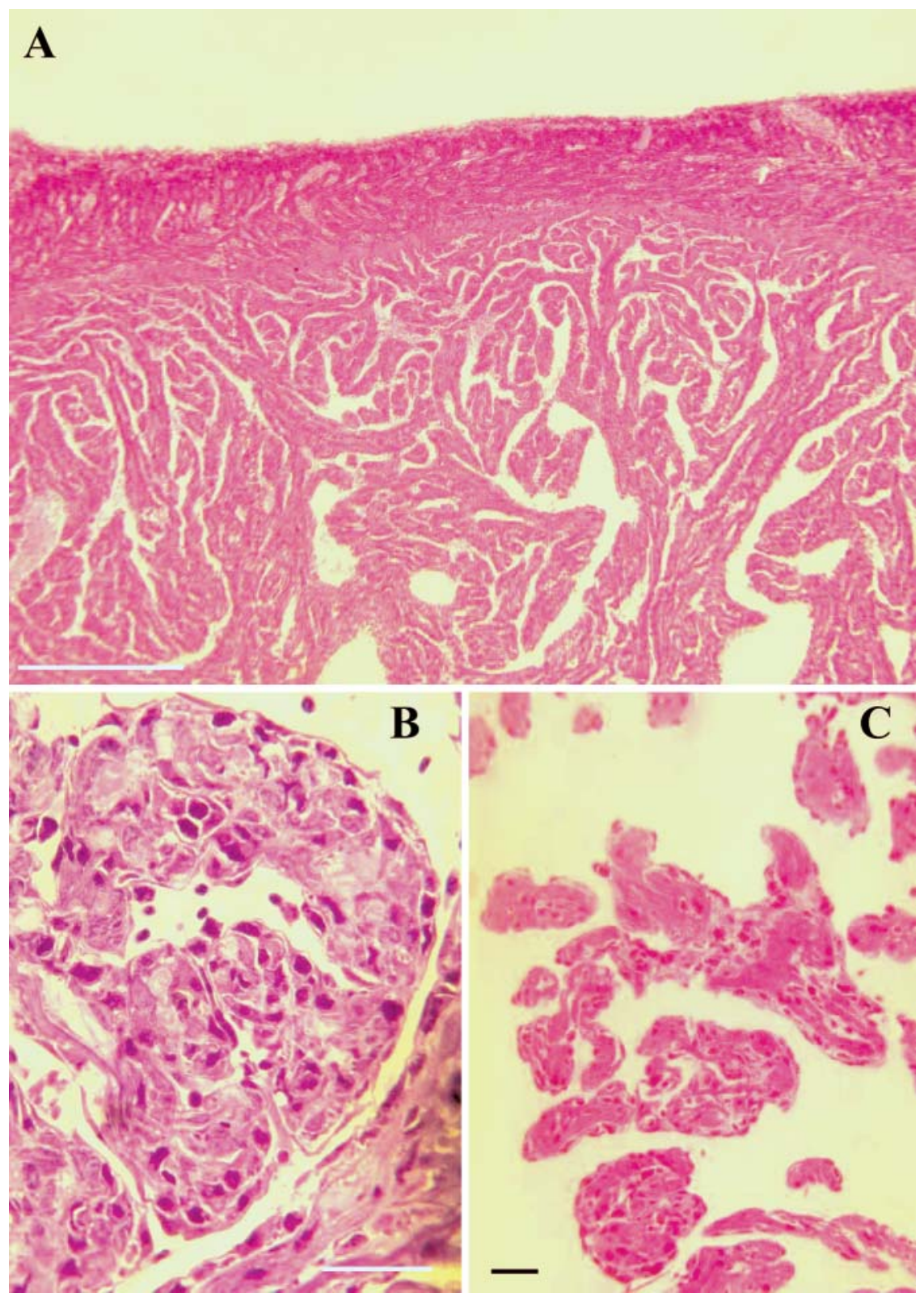

Fig. 1. Heart and skeletal muscle inflammation (HSMI) in Salmo salar. Lesions in the (A,B) heart ventricle and (C) atrium of salmon suffering from HSMI. The myocardium was infiltrated by leukocytes. These inflammatory cells were localized within and around necrotic myofibers. (A) Scale bar $=0.8 \mathrm{~mm}$. (B,C) Scale bars $=40 \mu \mathrm{m}$

The salmon with HSMI were also screened for presence of ISAV, NSAV, IPNV, and ASPV, but none of these viruses were consistently present in all farms. ISAV was present in 5 fish from one farm, and 2 fish in a second farm were positive for IPNV, but the cycle threshold (Ct)-values for all these were higher than 35. No fish were positive for NSAV or ASPV.

TEM studies showed that 5 different virus-like particles were present in salmon with HSMI. One of these was the erythrocytic inclusion body syndrome (EIBS) virus that is about 80 to $100 \mathrm{~nm}$ in diameter with an electron-dense nucleus of about $40 \mathrm{~nm}$ (Fig. 3). This virus was present in vacuoles in erythrocytes from all salmon in all 4 farms included in this study. Large amounts of EIBS virus were also present in vacuoles of unidentified head kidney cells (Fig. 3). It was not possible to culture this virus in the available cell cultures, i.e. TEM studies of cell cultures did not reveal any EIBS virus.

The second virus-like particle (VLP-2) is about the same size as EIBS virus, but with a different morphology (Fig. 4), and was observed in 4 salmon from 1 of 
the marine farms. The VLP-2 is enveloped, about $80 \mathrm{~nm}$ in diameter, surrounded by a thick layer of amorphous material (surface proteins), and has a rodshaped nucleocapsid. This virus was seen in cells in the atrium of the heart and head kidney. It was not possible to culture this virus in ASK or CHSE-214 cells, i.e. TEM studies of cell cultures did not reveal any of the VLP-2.

In addition to the EIBS virus and the VLP-2, a third $80 \mathrm{~nm}$, intra-vacuolar, virus-like particle (VLP-3) was present in 3 salmon from the same farm as the VLP-2 particles (Fig. 4C). These particles are enveloped, but lack a distinct nucleocapsid, like that of the EIBS virus or VLP-2, inside the particles. The VLP-3 particles were present in macrophages in the kidney.
In addition to the 3 above-mentioned 80 to $100 \mathrm{~nm}$ particles, 2 other VLPs, similar to those described from smolt suffering from HSS (Nylund et al 2003), were consistently found in all salmon with HSMI. These particles were named Type I, $60 \mathrm{~nm}$ in diameter, and Type II, about $50 \mathrm{~nm}$ in diameter, by Nylund et al. (2003). The Type I particles were found intracellularly in blood vessel endothelial cells, endocardial cells and granulocytes. These Type I particles were found in the same cells in salmon suffering from HSMI (Fig. 5) and were located in intracellular vacuoles containing amorphous materials.

The Type II particles were also found in the same cells as described by Nylund et al. (2003), i.e. in muscle cells, endothelial cells lining blood vessels, endocardial cells and unidentified cells in the kidney (Fig. 6). Both Type I
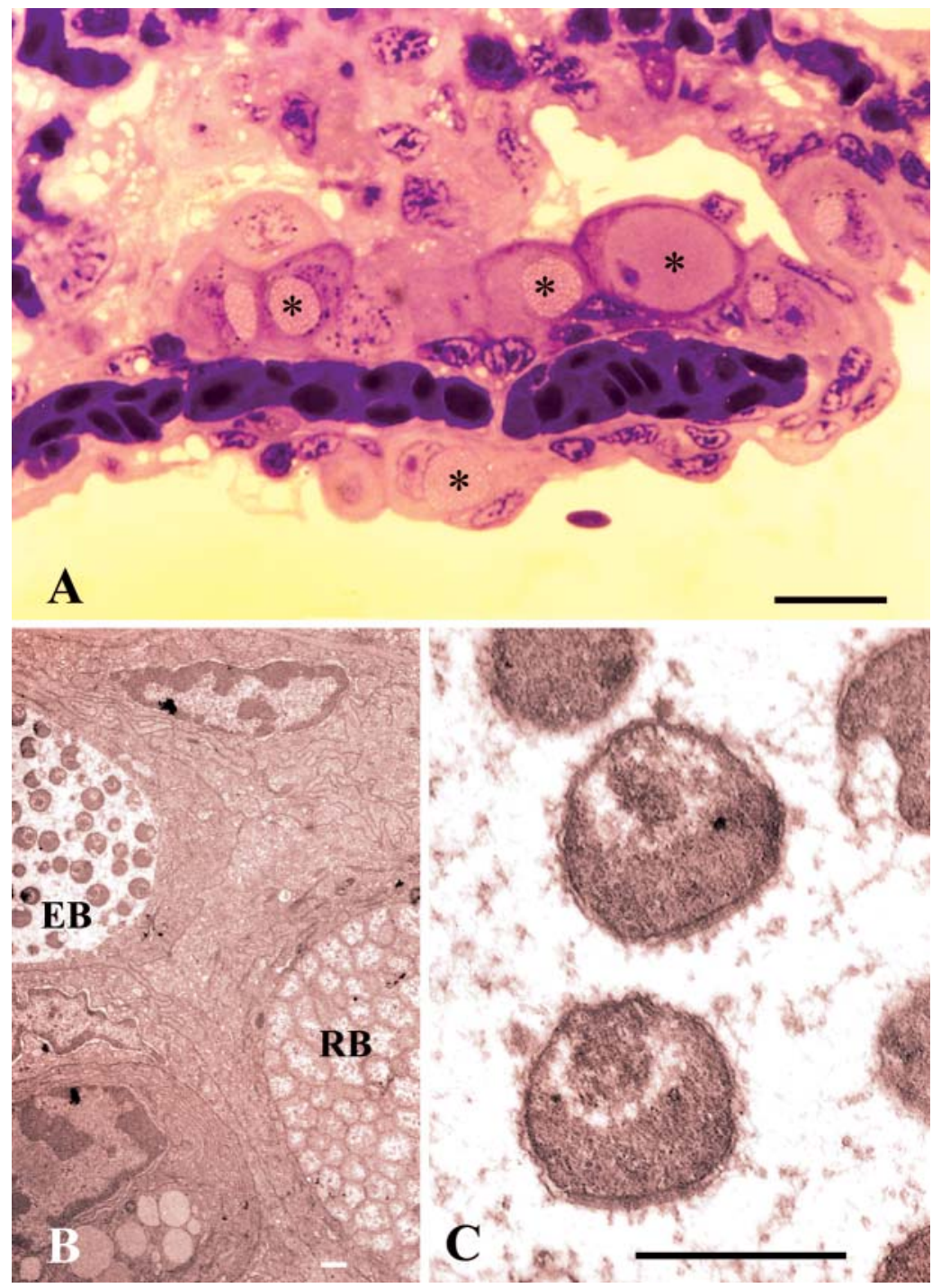

Fig. 2. HSMI in Salmo salar. Epitheliocystis agent from salmon suffering from HSMI. (A) Section through a secondary lamellae showing several epithelial cells infected with an epitheliocystis agent (*). Scale bar $=0.2 \mathrm{~mm}$. (B) TEM picture showing different developmental stages, reticulate bodies (RB) and elementary bodies (EB) of the epitheliocystis agent. Scale bar $=0.5 \mu$.

(C) Magnification of 2 EBs of the epitheliocystis agent. Scale bar $=0.5 \mu \mathrm{m}$ 


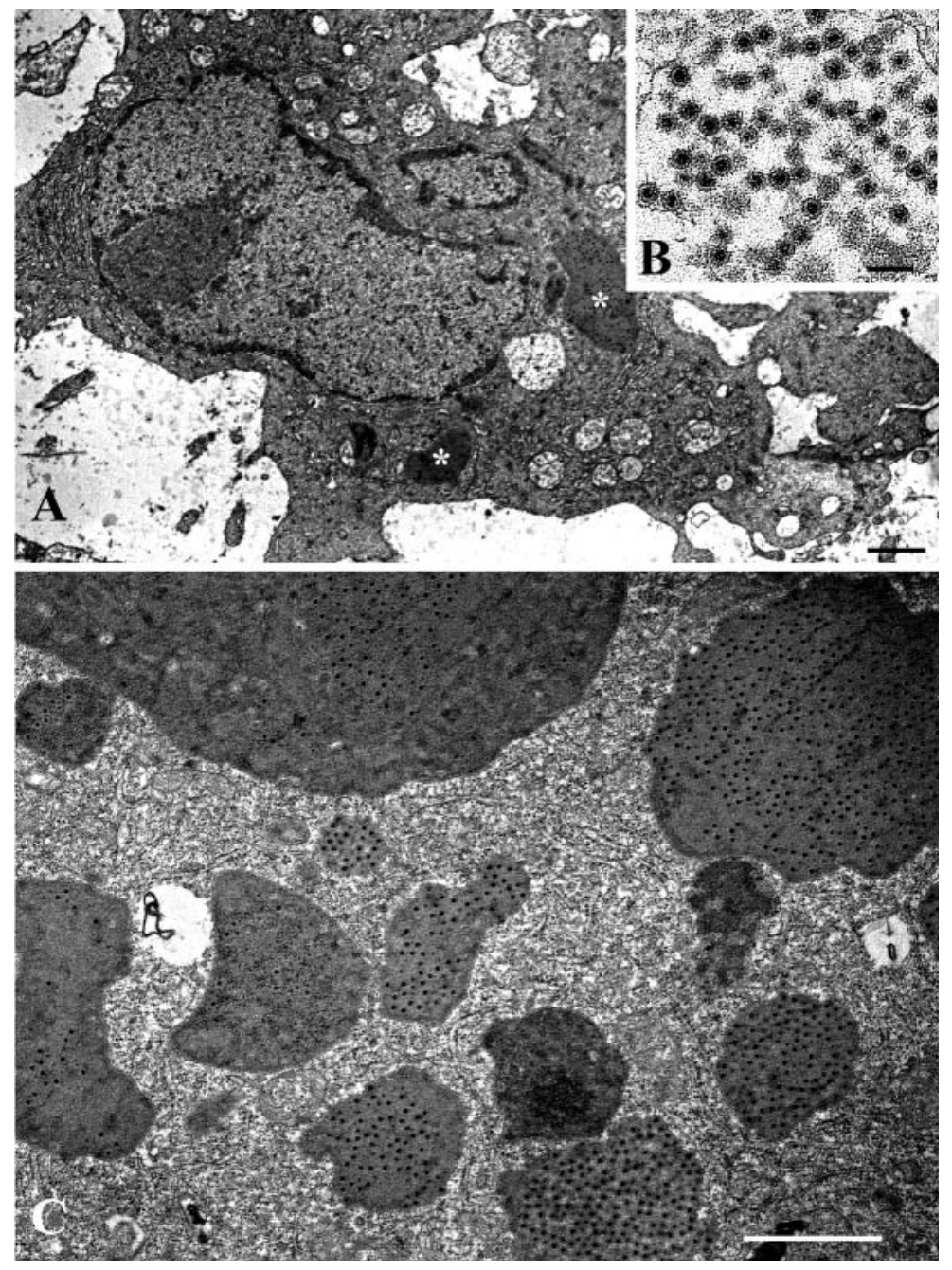

Fig. 3. HSMI in Salmo salar. Erythrocytic inclusion body syndrome (EIBS) virus in salmon suffering from HSMI. (A) Head kidney cell infected with EIBS virus. (*) Virus inclusions. Scale bar $=1.0 \mu \mathrm{m}$. (B) Magnification of the EIBS virus (80 nm in diameter). Scale bar $=200 \mathrm{~nm}$. (C) Membrane-bound electron-dense inclusions containing EIBS virus in an unidentified head kidney cell. Scale bar $=1.2 \mu \mathrm{m}$

and Type II particles were observed to be present at the same time in blood vessel endothelial cells. The Type II particles are $50 \mathrm{~nm}$ in diameter, have an electron-dense core (about $20 \mathrm{~nm}$ in diameter) and were present in intracellular vacuoles and in intercellular space.

\section{Cell culture}

The homogenates from all salmon suffering from HSMI resulted in a rapid (after $4 \mathrm{~d}$ ) and distinct CPE in the ASK cells (Fig. 7). There was no CPE in CHSE-214 cells or in the control ASK cells. Transferring supernatant from infected cells resulted in the same CPE as observed in the first passage. However, fewer cells showed the distinct CPE observed $4 \mathrm{~d}$ after the primary inoculation.
Two VLPs were found in ASK cells showing CPE, Type I and Type II particles (Fig. 8). Both particles, which have the same characteristics as described above, were sometimes present in the same cell.

\section{DISCUSSION}

The materials used in this study were all collected from salmon officially diagnosed with HSMI and should be representative of the disease. The diagnosis was also confirmed by our observation of semithin section from the heart and somatic muscles of all salmon included in the study. Since it has been shown that HSMI is a transmissible disease (Kongtorp et al. 2004a, A. Nylund pers. obs.), it can be expected that these salmon will most likely contain the causal 
agent(s). Homogenates used in challenge experiments were filtered $(0.22 \mu \mathrm{m})$ and, hence, indicate that the disease is caused by viruses or very small bacteria (A. Nylund pers. obs.).

Examination of the fish for the presence of macroand microparasites seems to have ruled out possible eukaryotic causal agents. The bacterium most frequently present was the epitheliocystis agent, but this agent was not present in the gills of salmon in 1 of the farms, i.e. we were not able to detect the agent by examination of sections from the gills or by PCR targeting Candidatus Piscichlamydia salmonis. There is always a possibility that a low infection could have been overlooked when screening histological sections. However, the apparent lack of this bacterium indicates that its role in the development of HSMI may not be important. All fish included in the study were screened for the presence of epitheliocystis agent using different combinations of primers directed against the $16 \mathrm{~S}$ sequence of Candidatus Piscichlamydia salmonis
(Drahgi et al. 2004). None of the fish were positive using these primers. This indicates that the epitheliocystis agents observed in the gills of salmon may include more than just 1 species of intracellular, intravacuolar, chlamydia-like bacteria (cf. Nylund et al. 1998), and that the bacterium presented in this paper is most likely different from that described by Drahgi et al. (2004). We have detected P. salmonis in salmon suffering from proliferative gill disease in western Norway (A. Nylund unpubl., Accession no. DQ310810), and this material was used as a positive control. Hence, our detection assay is working.

EIBS viruses have been described from several different fish species and from farmed Atlantic salmon in most salmon producing countries (Leek 1987, Arakawa et al. 1989, Piacentini et al. 1989, Lunder et al. 1990, Rodger et al. 1991, Michak et al. 1992, Rodger \& Richards 1998a, Graham et al. 2002, Nylund et al. 2003). Presence of these viruses was associated with both mortalities and anaemia, but it is uncertain if the EIBS virus

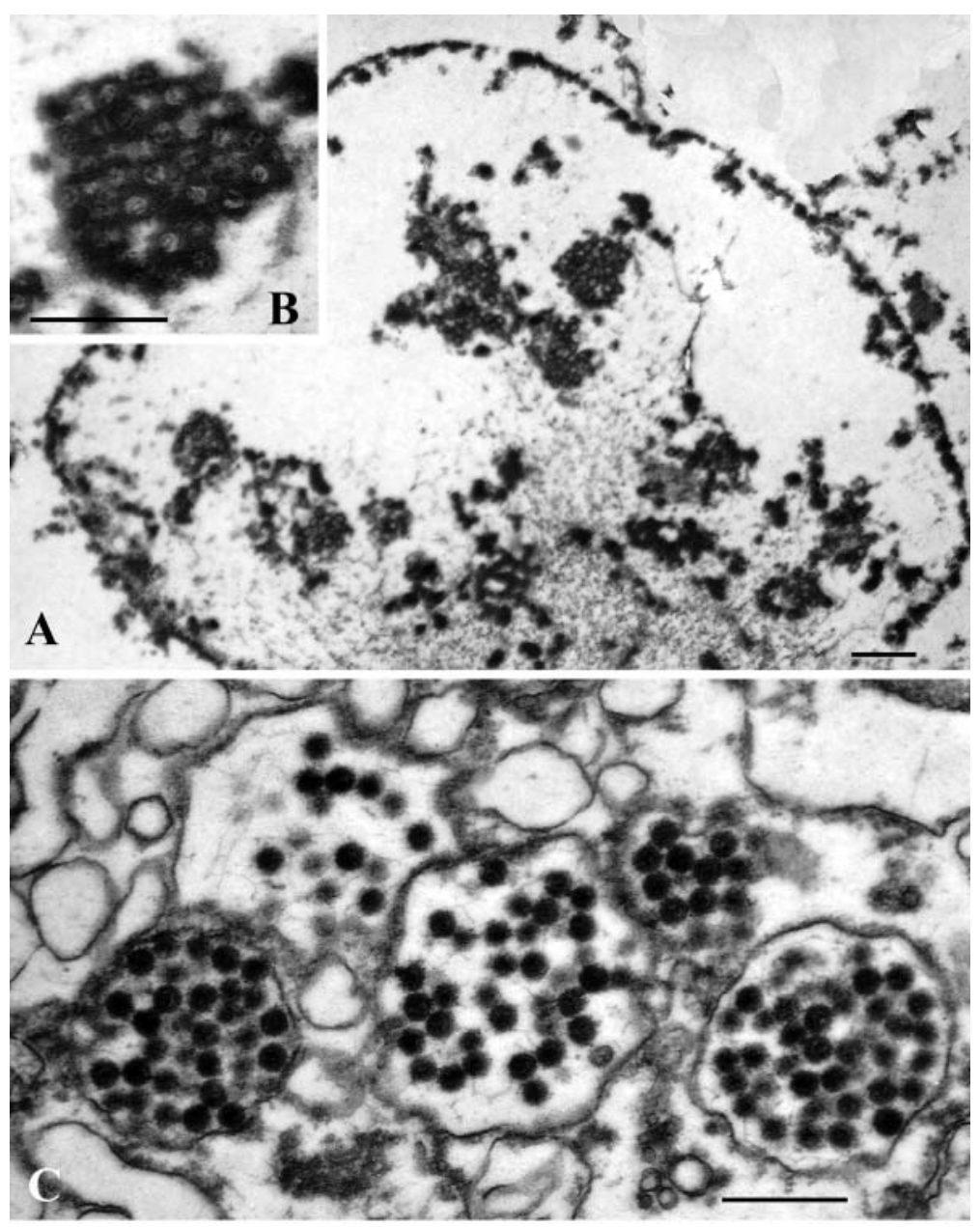

Fig. 4. HSMI in Salmo salar. Virus-like particle 2 (VPL-2). (A) Unidentified necrotic cell containing VPL-2. Scale bar $=0.5 \mu$ m. (B) Magnification of the VPL-2 showing the rod-shaped nucleocapsid. Scale bar $=0.3 \mu \mathrm{m}$. (C) Virus-like particle 3 (VPL-3) that is slightly similar to both EIBS virus and VLP-2. These particles are located inside intracellular vacuoles. Scale bar $=0.4 \mu \mathrm{m}$ 

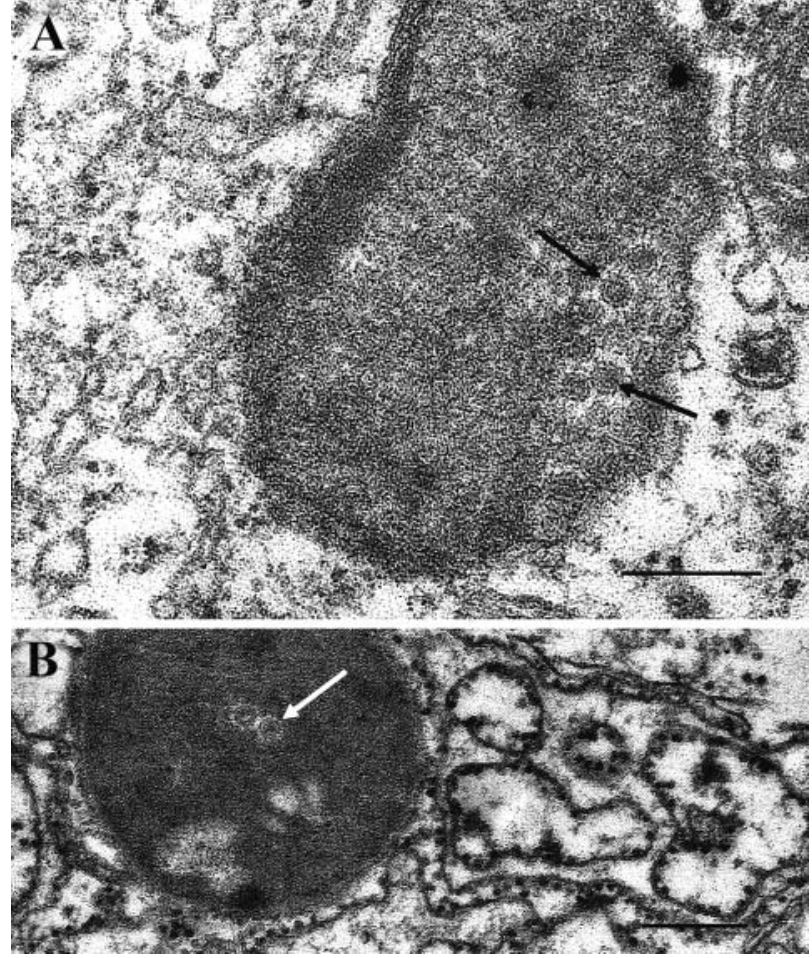

Fig. 5. HSMI in Salmo salar. (A, B) Type I particles (about $60 \mathrm{~nm}$ ) located within rough endoplasmatic reticulum (RER) cisternae of infected cells in salmon suffering from HSMI (arrows). Scale bars $=0.3 \mu \mathrm{m}$

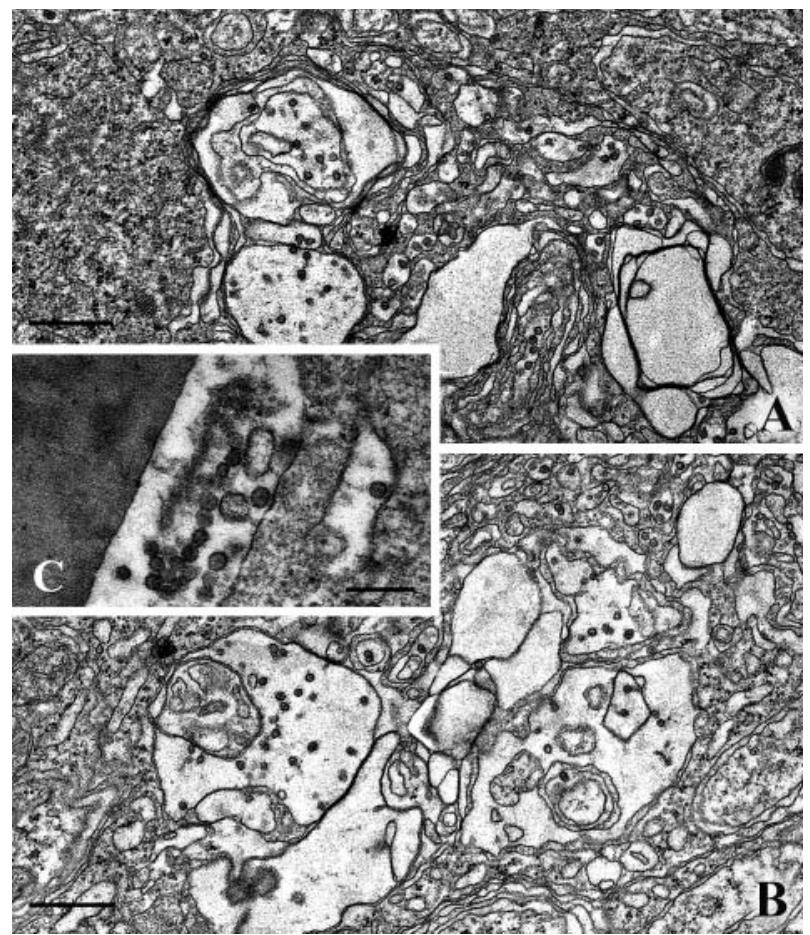

Fig. 6. HSMI in Salmo salar. Type II particles in infected cells from salmon suffering from HSMI. (A,B) Overview of cell vacuoles containing Type II particles. Scale bars $=0.6 \mu \mathrm{m}$. (C) Magnification of the Type II particle. Scale bar $=0.25 \mu \mathrm{m}$

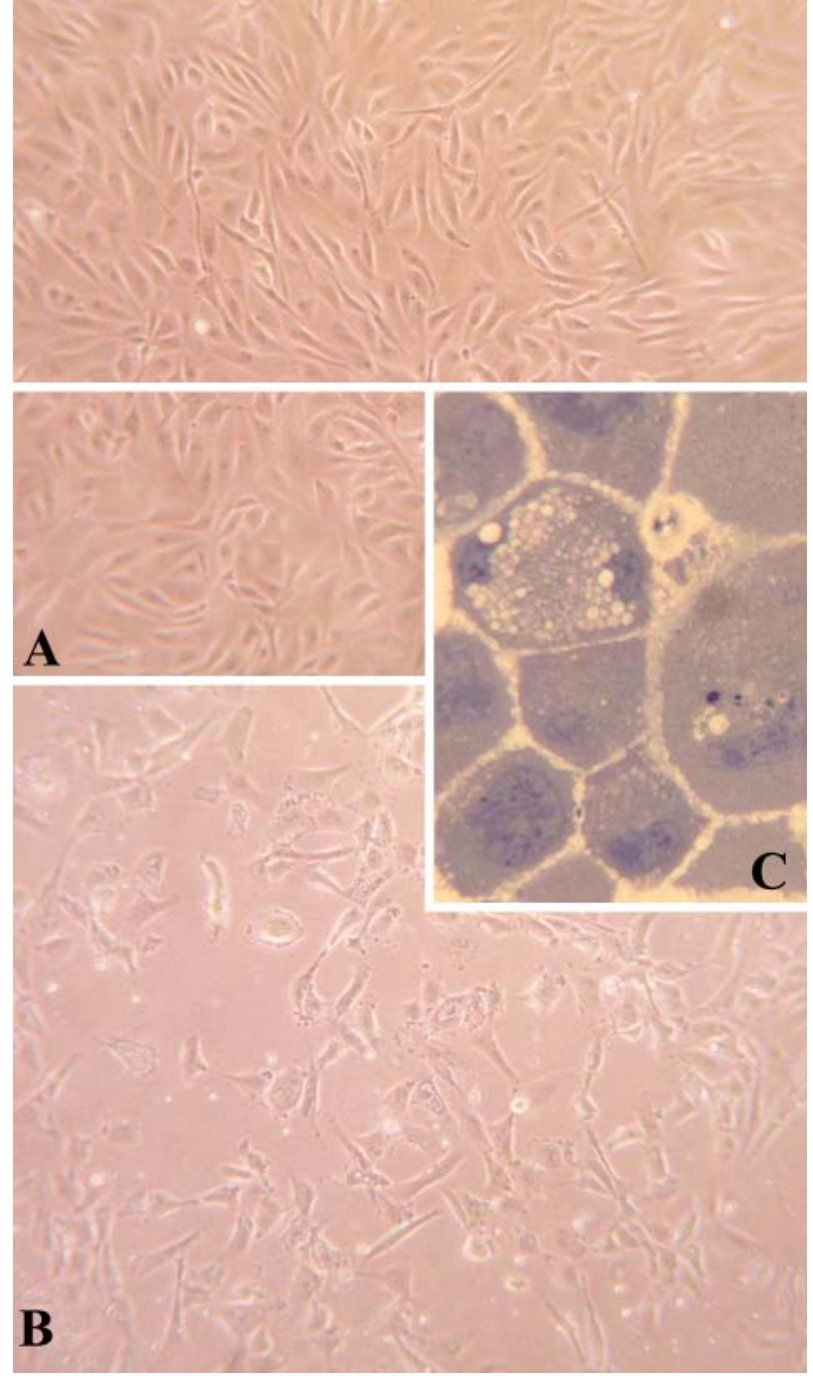

Fig. 7. HSMI in Salmo salar. (A) Control ASK cells. (B) ASK cells inoculated with homogenates from salmon suffering from HSMI. (C) Section of ASK inoculated with HSMI homogenate

was the causal agent. At present it is not possible to know if the EIBS viruses represent 1 species or several related species of viruses. If the EIBS virus in salmon is 1 species, then the variant that is associated with HSMI must be highly virulent or the EIBS virus is not solely responsible for the disease. However, EIBS virus was present in all salmon with HSMI included in this study. It has not been possible to culture the EIBS virus in existing cell cultures, nor are there any molecular diagnostics available for detecting presence of the virus. This fact puts serious limits on studies of this virus and its importance in connection with diseases in salmonid cultures.

The Type I and Type II viruses found in fish suffering from HSS were present in all salmon included in this study and in cell cultures (ASK cells) inoculated 
with homogenates from salmon suffering from HSMI (Nylund et al. 2003, present study). This is, of course, is not evidence of a causal relationship between the Type I/Type II viruses and HSMI, but suggests that these viruses are promising candidates as causal agents together with the EIBS virus. If the Type I and Type II VLPs are 2 different viruses, their size, morphology and replication suggest affinities to the family Togaviridae, including Alphavirus, Rubellavirus, and Flavivirus (Knipe \& Howley 2001). Only characterization of the genome from these viruses can resolve this question.

One of the cases of HSMI presented in this study, i.e. postsmolts suffering from HSMI in sea cages, had a history as smolt suffering from HSS in the freshwater phase. The postsmolt developed HSMI only $14 \mathrm{~d}$ after sea release. This short time in the sea suggests that HSMI may be caused by pathogens already present in the freshwater phase of the salmon, unless HSMI is caused by 1 or several agents with an extreme potential to spread and a short incubation time in the seawater, which we find unlikely. HSS commonly occurs in smolt production sites in Norway (Nylund et al. 2003) and a connection between these 2 diseases cannot be excluded. Lack of HSMI in northern Norway partly contradicts this hypothesis since a lot of smolt that are sea released in this part of Norway have a history of HSS in freshwater. However, external factors like temperature or stress may play a role in the development of HSMI.

It has also been speculated that salmonid alphaviruses (SAV) may play a role as a causal agent of HSMI (Ferguson et al. 2005). The present study found no evidence to support such a claim. All salmon included in this study were screened by real time RT-PCR and were found to be negative for NSAV. The real time RT-PCR was developed by Hodneland et al. (2005) and is able to detect all 3 subtypes of salmonid alphaviruses (SAV) known in Europe. A challenge study, using the Norwegian SAV, has shown that nearly all salmon end up as carriers (Andersen 2005); hence, if NSAV had played a role in the development of HSMI, we should have been able to detect the virus. The other 2 SAV, salmon pancreas disease virus (SPDV) and sleeping disease virus (SDV), have not been detected in Norway (Karlsen et al. 2005). Also, first cases of HSMI in Norway occurred in Trøndelag, where SAV has not been found so far.

There is no experimental evidence of a causal relationship between 1 or several of the VLPs described above and HSMI, but the presence of viruses does strengthen the hypothesis of a possible viral cause for HSMI. Further, ongoing studies of tissues collected from salmon challenged with the disease should give more reliable information about the causal agent of HSMI.

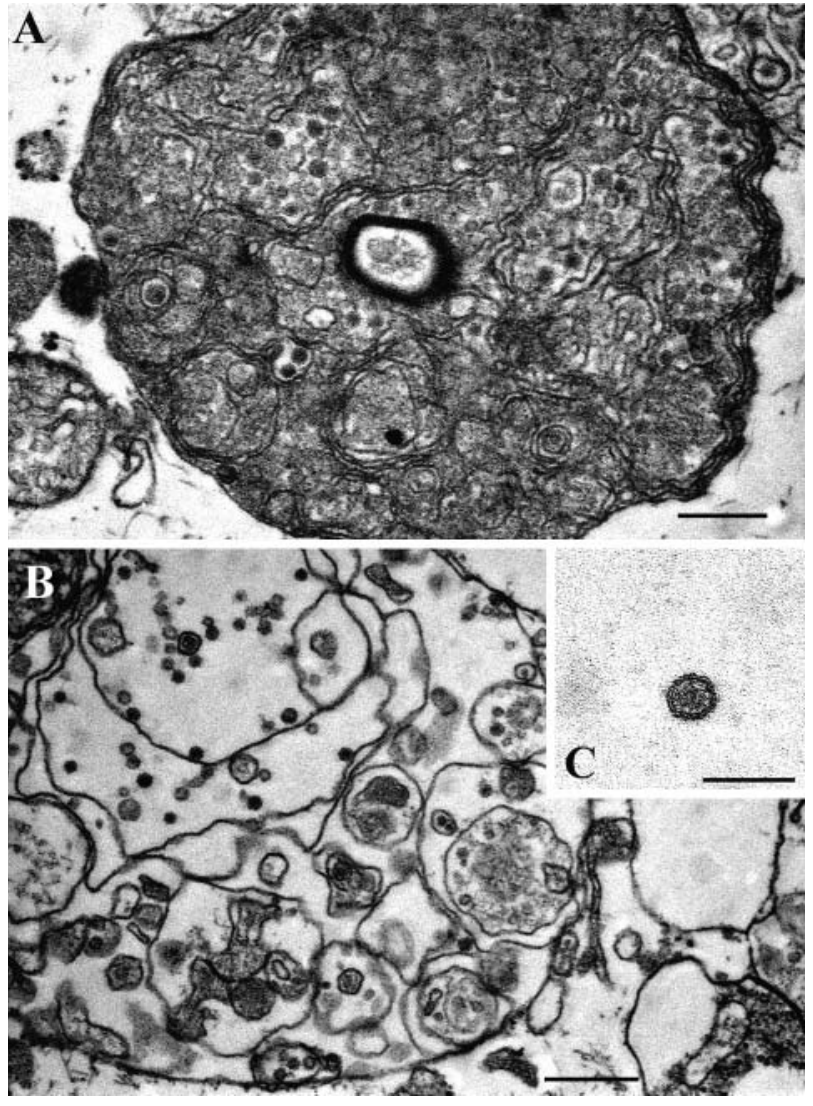

Fig. 8. HSMI in Salmo salar. (A) Type I and (B) Type II particles in ASK cells inoculated with homogenates from salmon suffering from HSMI. Scale bars $=0.3 \mu \mathrm{m}$. (C) Magnification of a Type II particle. Scale bar $=100 \mathrm{~nm}$

\section{LITERATURE CITED}

Andersen L (2005) Tissue tropism of the Norwegian salmonid alphavirus (NSAV) in experimental challenged Salmo salar. Master thesis, Department of Biology, University of Bergen

Arakawa CK, Hursh DA, Lannan CN, Rohovec JS, Winton JR (1989) Preliminary characterization of a virus causing infectious anemia among stocks of salmonid fish in the western United States. In: Ahne W, Kurstak E (eds) Viruses of lower vertebrates. Springer-Verlag, Berlin, p $442-450$

Devold M, Krossøy B, Aspehaug V, Nylund A (2000) Use of RT-PCR for diagnosis of infectious salmon anaemia virus (ISAV) in carrier sea trout Salmo trutta after experimental infection. Dis Aquat Org 40:9-18

Drahgi A, Vsevolod LP, Kahl MM, Stanton JB, Brown CC, Tsongalis G, West AB, Frasca S (2004) Characterization of 'Candidatus Piscichlamydia salmonis' (Order Chlamydiales), a Chlamydia-like bacterium associated with epitheliocystis in farmed Atlantic salmon (Salmo salar). J Clin Microbiol 42(11):5286-5297

Ferguson HW, Poppe T, Speare DJ (1990) Cardiomyopathy in farmed Norwegian salmon. Dis Aquat Org 8:225-231

Ferguson HW, Kongtorp RT, Taksdal T, Graham D, Falk K (2005) An outbreak of disease resembling heart and skeletal muscle inflammation in Scottish farmed salmon, Salmo 
salar L., with observations on myocardinal regeration. J Fish Dis 28:119-123

Graham DA, Curran W, Rowley HM, Cox DI, Cockerill D, Campbell S, Todd D (2002) Observation of virus particles in the spleen, kidney, gills and erythrocytes of Atlantic salmon, Salmo salar L., during disease outbreak with high mortality. J Fish Dis 25:227-234

Hodneland K, Bratland A, Christie KE, Endresen C, Nylund A (2005) New subtype of salmonid alphavirus (SAV), Togaviridae, from Atlantic salmon Salmo salar and rainbow trout Oncorhynchus mykiss in Norway. Dis Aquat Org 66:113-120

Karlsen M, Hodneland K, Endresen C, Nylund A (2005) Genetic stability within the Norwegian subtype of salmonid alphavirus (family Togaviridae). Arch Virol 151(5):861-874

Knipe DM, Howley PM (2001) Fields virology. Lippincott Williams \& Wilkins, Philadelphia, PA

Kongtorp RT, Kjerstad A, Taksdal T, Guttvik A, Falk K (2004a) Heart and skeletal muscle inflammation in Atlantic salmon, Salmo salar L.: a new infectious disease. J Fish Dis 27:351-358

Kongtorp RT, Taksdal T, Lyngøy A (2004b) Pathology of heart and skeletal muscle inflammation (HSMI) in farmed Atlantic salmon Salmo salar. Dis Aquat Org 59:217-224

Leek SL (1987) Viral erythrocytic inclusion body syndrome (EIBS) occurring in juvenile spring Chinook salmon (Oncorhynchus tshawytscha) reared in freshwater. Can J Fish Aquat Sci 44:685-688

Lunder T, Thorud K, Poppe TT, Holt RA, Rohovec JS (1990) Particles similar to the virus of erythrocytic inclusion body syndrome, EIBS, detected in Atlantic salmon (Salmo salar) in Norway. Bull Eur Assoc Fish Pathol 10 (1):21-23

Michak P, Smith CE, Hopper K (1992) Erythrocytic inclusion body syndrome: a light and electron microscopic study of infected erythrocytes of Chinook Oncorhynchus tshawytscha

Editorial responsibility: Jo-Ann Leong,

Kaneohe, Hawaii, USA and coho O. kisutch salmon. Dis Aquat Org 12:229-233

Mukhopadhyay S, Kuhn RJ, Rossmann MG (2005) A structural perspective of the Flavivirus cycle. Nat Rev Microbiol $3: 13-22$

Nylund A (2001) Cardiomyopathy syndrome (CMS). Fiskehelse 1:29-37 (in Norwegian)

Nylund A, Hovland T, Watanabe K, Endresen C (1995) Presence of infectious salmon anaemia virus (ISAV) in tissues of Atlantic salmon, Salmo salar L., collected during three separate outbreaks of the disease. J Fish Dis 18:135-145

Nylund A, Kvenseth AM, Isdal E (1998) A morphological study of the epitheliocystis agent in farmed Atlantic salmon. J Aquat Anim Health 10:43-55

Nylund A, Plarre H, Hodneland K, Devold M, Aspehaug V, Aarseth M, Koren C, Watanabe K (2003) Haemorrhagic smolt syndrome (HSS) in Norway: pathology and associated virus-like particles. Dis Aquat Org 54:15-27

Piacentini SC, Rohovec JS, Fryer JL (1989) Epizootiology of erythrocytic inclusion body syndrome. J Aquat Anim Health 1:173-179

Plarre H, Devold M, Snow, M, Nylund A (2005) Prevalence of infectious salmon anaemia virus (ISAV) in wild salmonids in western Norway. Dis Aquat Org 66:71-79

Rodger HD, Richards RH (1998a) Observational study of erythrocytic inclusion bodies in farmed Atlantic salmon, Salmo salar L., in the British Isles. J Fish Dis 21:101-111

Rodger HD, Richards RH (1998b) Haemorrhagic smolt syndrome: a severe anaemic condition in farmed salmon in Scotland. Vet Rec 142:538-541

Rodger HD, Drinan EM, Murphy TM, Lunder T (1991) Observations on erythrocytic inclusion body syndrome in Ireland. Bull Eur Assoc Fish Pathol 11(3):108-111

Watanabe K, Devold M, Myhr E, Lyngøy A, Isdal E, Fridell F, Nylund A (2003) Heart and skeletal muscle inflammation (HSMI): a new viral disease? Fiskehelse 2:23-30 (in Norwegian)

Submitted: February 3, 2005; Accepted: January 17, 2006 Proofs received from author(s): June 9, 2006 